\title{
CO Oxidation over Metal Oxide Catalyst Supported by Indonesian Natural Zeolite
}

\author{
Suryo Purwono \\ Department of Chemical Engineering, Gadjah Mada University \\ Jl. Grafika No. 2, Yogyakarta, INDONESIA. \\ Fax : 0274 902170, e-mail : tkftugm@indosat.net.id
}

\begin{abstract}
The objectives of this study are to attempt to develop catalysts and to find the operating conditions under which combustible waste gases concentrations in the exhaust gases can be eventually reduced to satisfy air pollution standards. The results shows that using impregnation method, nickel and vanadium metals, as active components of the catalyst, can be dispersed on the natural zeolite as catalyst support.
\end{abstract}

\begin{abstract}
The reaction rate measurements of catalytic oxidation of $\mathrm{CO}$ was done in the temperature range between 300 and $550^{\circ} \mathrm{C}$ using a differential micro-reactor. The catalysts used for this experiment were vanadium pentoxide and nickel oxide on activated natural zeolite. To avoid fluidization, the reactant gases were flowed downward. The results show that the reaction rate depends strongly on the bed temperature and feed concentration and is not controlled by bulk phase mass transfer and pore diffusion.
\end{abstract}

\section{INTRODUCTION}

Among the most complex problem to be faced by industries since industrial revolution are the problems of air pollution. The main pollutant coming from industries and automotive exhaust is carbon monoxide. This pollutant is very dangerous for human life. As little as $0.07 \%$ of $\mathrm{CO}$ is capable, over a period time, of saturating $50 \%$ of the blood hemoglobin, while a few breaths of $1.0 \%$ CO may cause 60 to $80 \%$ saturation and death. It should be noted that shortness of breath and possibility of slight headache may occur after 8 hours in a $\mathrm{CO}$ concentration of $0.01 \%$ (Theodore and Buonicore, 1988; and Matros, 1989).

The rapid growth of industry in Indonesia has resulted in a progressive increase in atmospheric pollution. It is thus of practical importance to study
CO oxidation, especially with respect to the control of $\mathrm{CO}$ pollution. Industrial waste gases can be oxidized further to be carbon dioxide and steam using catalyst made of metal or metal oxide supported by many materials. However, the existing catalysts were too expensive to be used in Indonesian industries. Hence, a new catalyst should be pursued to handle these kind of gases. The catalyst should be cheap, simple and efficient.

Natural zeolites are an economically and environmentally important classes of minerals that occur in significant abundance in Indonesia. Forty-seven zeolite deposits have been discovered mainly in Sumatra, Java and Nusa Tenggara (Husaini and Hardjatmo, 1996). Due to the special structure of zeolite, they have many important commercial properties such as high efficient adsorption and molecular sieve effect, cation exchange effect, property of catalyst, high 
activity, high strength and light mass. These properties make zeolite having a wide variety of purposes. Uses of natural zeolite from Indonesia deposit have been promoted proportionally, however the application is still limited. It is mainly due to the limitation basic research to match the specific zeolite with specific use. Therefore, this research will explore the use of natural zeolite as a fundamental data for deciding the alternative support for oxidative catalyst.

Although the oxidation of carbon monoxide on metal oxide catalyst is among the oldest known catalytic reactions, and has been studied by many researchers, the conclusions regarding the mechanisms and the rate equations are rather conflicting. Some researchers found that the reaction follows Langmuir-Hinschelwood (Voltz et al., 1973; and Nishiyama and Wise, 1974) and others believed that the $\mathrm{CO}$ oxidation on metal catalyst are an Eley-Rideal type reaction (Mc Charty et al., 1975). A part of the reason for the disagreements in the published work is the narrowness of the ranges of temperature and concentration of the reactants $\mathrm{CO}$ and oxygen. Also since the metal oxide catalyst is highly active for the oxidation of $\mathrm{CO}$, the measured oxidation rate could be appreciably affected by mass transfer limitation.

The main objectives of this paper are to oxidize $\mathrm{CO}$ on metal catalyst supported by natural zeolite and to find model for kinetic of $\mathrm{CO}$ oxidation that will accurately predict oxidation rate under different temperatures and feed concentrations. This steady state kinetic studies can be used to support the mathematical modeling since a suitable reaction rate expression is essential for a successful reactor model. This paper consists of two parts, the first one concerns data analysis and results while the second one deals with modeling of the reaction kinetics.

\section{EXPERIMENTAL}

\section{Catalyst development}

For this step, nickel oxide and vanadium pentoxide catalyst supported on activated zeolite have been developed. Procedure of catalyst development includes several stages: activation of catalyst support, impregnation and calcinations. Several procedure and parameter conditions in the process of catalyst development have been made in order to get optimum result.

\section{Catalyst support}

The zeolite used in this experiment was from West Java. The results of mineral identification is shown in Table 1 . The samples composed of a mixture of mordernite and clinoptilolite. Some samples were also associated with other minerals such as montmorilonite and quartz. According to Bales (1988), the variation of zeolite composition in the samples was depend upon any factors such as the influence of fluid composition zeolite minerology, significance of associated clays, pressure and temperature, chemical stability relation among various zeolite and kinetic relation. The variation of mordernite and clinoptilolite distribution also are controlled by the volcanoclastic as parent material of zeolite as well as degree of zeolitisation. There are three variation of zeoilte activation : using temperature, acid solution and basic solution. According to Kharisun and Budiono (1999), acid activation tends to increase $\mathrm{pH}, \mathrm{EC}, \mathrm{CEC}$ and chemical and exchangeable bases. Therefore for this experiment, the zeolite was activated using acid treatment.

For activation of catalyst support, the $20 \mathrm{~g}$ of natural zeolite granular were put in $50 \mathrm{ml}$ $\mathrm{NH}_{4} \mathrm{NO}_{3}$ solution and stirred for 12 hours. Then left it for another 12 hours. Then the sample were filtered using whatman paper and washed with deionised water. After that, the sample were then dried in oven with temperature of $110^{\circ} \mathrm{C}$ for 4 hours. For the activation, the zeolite granular were heated up to $700{ }^{\circ} \mathrm{C}$ while flowing nitrogen gas for 4 hours in a reactor having $2 \mathrm{~cm}$ diameter and $40 \mathrm{~cm}$ length.

\section{Catalyst preparation}

The catalyst was prepared using dipping and vaporization methods. First of all, activated zeolite was sieved to get particles having diameter of 1 $\mathrm{mm}, 2.5 \mathrm{~mm}$ and $5 \mathrm{~mm}$. Then nickel or vanadium solution was dissolved in the water stoichiometrically and the zeolite was put in the solution and stirred for 24 hours. The solution was dried and heated in an electrical stove and dried further in an oven. The calcinations was 
conducted in $1 \mathrm{ml} / \mathrm{sec}$ nitrogen stream for 4 hours at $600^{\circ} \mathrm{C}$. The amount of metal was varied in the range of 1 to $4 \%$.

\section{Catalyst characterization}

The solid catalyst obtained was characterized by using BET surface area analyzer utilizing liquid nitrogen as a probe molecule to find out surface area and pore size of the catalyst. The morphology (catalyst's surface texture) was observed using a Scanning Electron Microscope. The amount of metal in the catalyst surface was determined by

Table 1. Chemical composition of zeolite samples

\begin{tabular}{|c|c|c|}
\hline \multirow{2}{*}{ No. } & \multicolumn{2}{|c|}{ Chemical compound } \\
\cline { 2 - 3 } & Type of chemical & $(\%)$ \\
\hline 1. & $\mathrm{SiO}_{2}$ & 69.81 \\
\hline 2. & $\mathrm{Al}_{2} \mathrm{O}_{3}$ & 13.52 \\
\hline 3. & $\mathrm{Fe}_{2} \mathrm{O}_{3}$ & 1.93 \\
\hline 4. & $\mathrm{TiO}_{2}$ & 0.21 \\
\hline 5. & $\mathrm{CaO}_{1}$ & 1.91 \\
\hline 6. & $\mathrm{MgO}$ & 0.89 \\
\hline 7. & $\mathrm{~K}_{2} \mathrm{O}$ & 1.93 \\
\hline 8. & $\mathrm{Na}_{2} \mathrm{O}$ & 1.24 \\
\hline 9. & Others & 8.56 \\
\hline
\end{tabular}

Source: Center of Mineral Research and development Technology, Directorate General of mines, Bandung, INDONESIA.

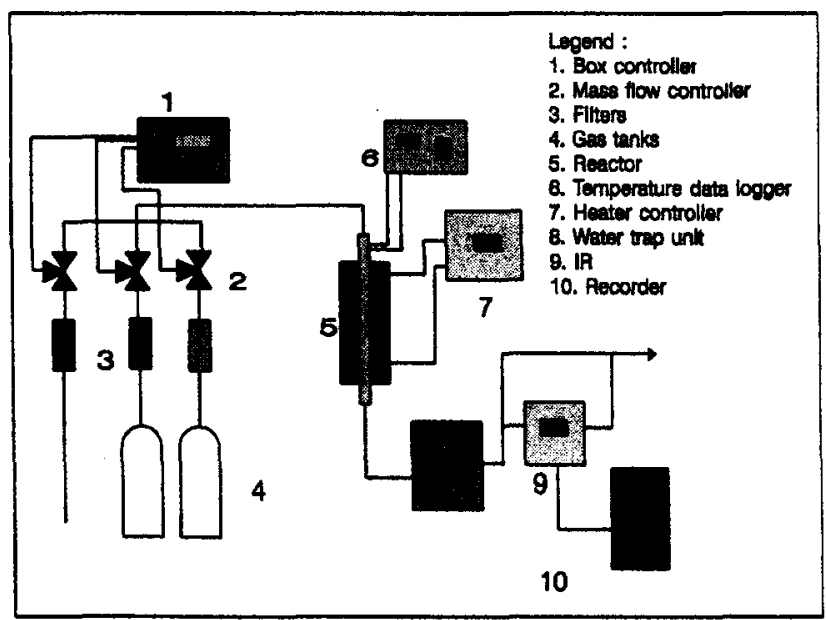

Figure1. Schematic diagram for $\mathrm{CO}$ and $\mathrm{HC}$ oxidation experiment.
Atomic Absorption Spectroscopy.

\section{Oxidation process}

The oxidation process was done in a differential reactor equipped with an IR analyzer for detecting $\mathrm{CO}, \mathrm{CO}_{2}$ and light hydrocarbon. For this experiment, pure $\mathrm{CO}$ was used as source gas where the compressed air was used for oxygen supply.

Figure 1 is a schematic diagram of the experimental set-up. All gases flowing to the reactor were dried over filters containing $4 \mathrm{~A}$ molecular sieves and anhydrous calcium sulphate to reduce traces of impurities. Omega flow transducer-controllers regulated the feed mass flow rate into the reactor. They permitted only uni-directional flow and therefore acted as check valves. The system operating pressure was measured by Omega pressure gauges. All the thermocouples in the system were connected to an Omega data logger. The reactor was $15 \mathrm{~cm}$ long and $0.635 \mathrm{~cm}$ ID stainless steel tubing. To prevent catalyst movement, stainless steel screens were installed at the inlet and outlet of the reactor.

Experiments were conducted under varying reactant concentrations, bed temperatures and flow rates. All runs were isobaric and carried out just above one atmosphere pressure.

\section{RESULTS AND DISCUSSION}

\section{Results of catalyst characterization}

The results of characterization of the catalyst developed are shown in Table 2 . The table shows the measurements of surface area, pore diameter and pore volume for nickel and vanadium catalysts supported on zeolite.

Catalyst development were done using two methods, vaporization and dipping. In the dipping method, the bonding between catalyst support and the metal was very weak, so that the metal was easily dissolved again into the washed water. Therefore, the amount of the metal impregnated was not the same as the metal added into the solution. The results of catalyst characterization show that, using the dipping method, the metal impregnated was only $70-80 \%$; whereas by using 
the vaporization method, the metal impregnated was almost $100 \%$. However, the distribution of metal in the catalyst support for dipping method was better than the vaporization method. I $t$ was also observed that increasing the concentration of metal ions will increase the metal content in catalyst. The increase of metal ions concentration in the solution will cause more collusion of the ions into support material so that adsorption of the ions into the solid become easier.

From the surface area measurement, it can be seen that the surface area increases when the diameter of the particle was decreased. On the other hand, when the concentration of the metal was increased, the total surface area decreased. Using the results of Scanning Electron Microscope (SEM), it can be seen that the area of the metal surface was bigger than the diameter of the pore on the catalyst support. Therefore, some of the metal blocked the pore, so that the surface area decreased as shown in Figure 2.

\section{Catalytic oxidation}

Several preliminary runs were made to test the catalytic activity of construction materials for the reactor (stainless steel), packing materials (pyrex beads) and thermocouple cement used in cementing thermocouples. This was done by passing the reactant stream through the heated reactor tube without catalyst. Conversion was not detectable. Thus, these materials are not active.

The data for the isothermal bed were gathered with the flow rate and reactant concentrations held constant while the varying temperature, ranging between 200 and $550^{\circ} \mathrm{C}$, depended on the feed gas. Experiments were repeated for reactant concentrations between 1.0 and $5.0 \%$. The flow rate was kept constant at 1200 or $1800 \mathrm{ml} / \mathrm{min}$ for all experiments. The catalyst used was $0.2 \mathrm{~g}$ for low feed concentrations and $0.1 \mathrm{~g}$ for high concentrations.
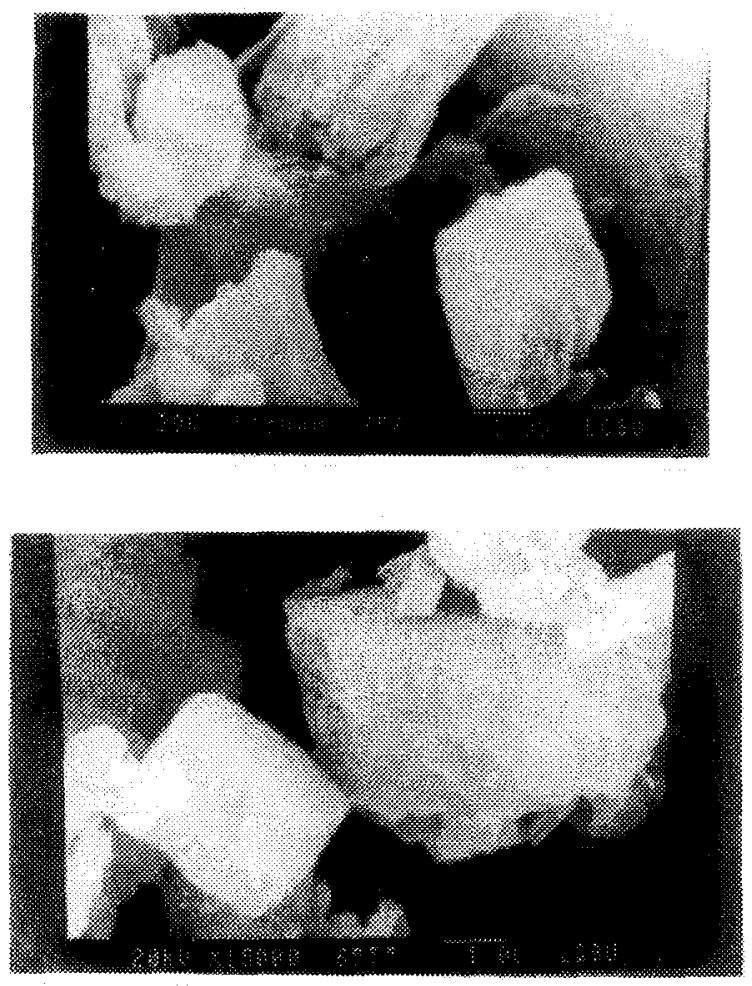

Figure 2. SEM image of Nickel catalyst supported by natural zeolite (2 and $4 \% \mathrm{Ni}$ )

Table 2. Results of catalyst characterization

\begin{tabular}{|c|c|c|c|c|c|c|}
\hline \multirow{2}{*}{$\begin{array}{c}\text { Metal } \\
\text { Concentration } \\
(\%)\end{array}$} & \multicolumn{3}{|c|}{ Nickel catalyst } & \multicolumn{3}{c|}{ Vanadium catalyst } \\
\cline { 2 - 7 } & $\begin{array}{c}\text { Surface } \\
\text { area } \\
\left(\mathrm{m}^{2}\right)\end{array}$ & $\begin{array}{c}\text { Pore } \\
\text { radius } \\
\left(\mathrm{A}^{\circ}\right)\end{array}$ & $\begin{array}{c}\text { Pore } \\
\text { volume } \\
\left(\mathrm{cm}^{3} / \mathrm{g}\right)\end{array}$ & $\begin{array}{c}\text { Surface } \\
\text { area } \\
\left(\mathrm{m}^{2}\right)\end{array}$ & $\begin{array}{c}\text { Pore } \\
\text { radius } \\
\left(\mathrm{A}^{\mathrm{o}}\right)\end{array}$ & $\begin{array}{c}\text { Pore volume } \\
\left(\mathrm{cm}^{3} / \mathrm{g}\right)\end{array}$ \\
\hline 0 & 19.3200 & 29.2210 & 0.0271 & 19.2998 & 28.8115 & 0.0278 \\
\hline 2 & 14.7720 & 23.4652 & 0.0173 & 22.7316 & 23.1730 & 0.0263 \\
\hline 4 & 12.9222 & 25.2572 & 0.0163 & 12.5383 & 26.2018 & 0.0164 \\
\hline
\end{tabular}




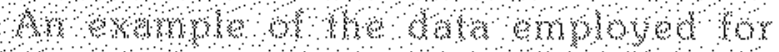

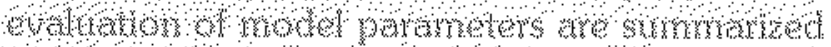

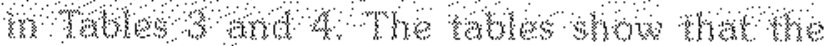

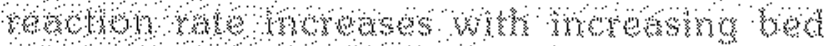

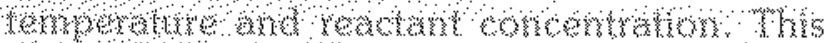

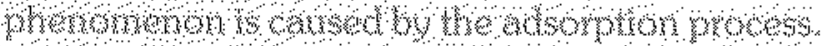

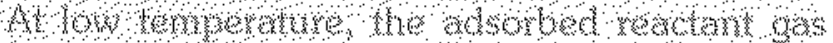

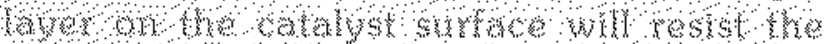

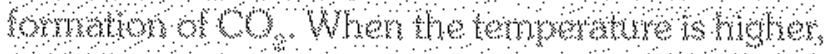

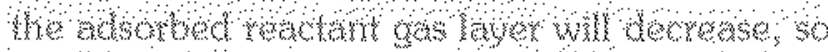

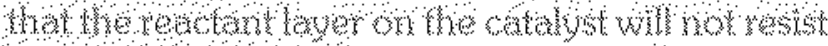

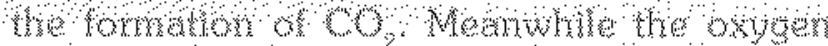

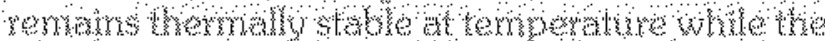

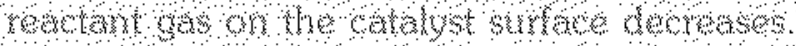

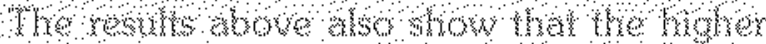

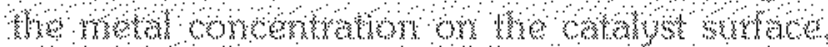

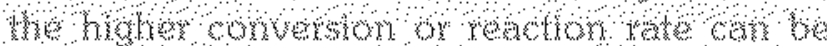

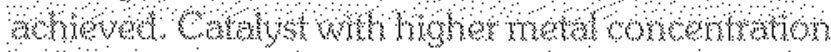

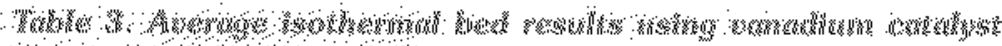

\begin{tabular}{ll}
\hline \\
\hline
\end{tabular}

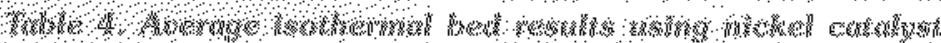

\begin{tabular}{|c|c|c|c|c|c|c|c|c|}
\hline \multirow{3}{*}{ का } & \multicolumn{8}{|c|}{ 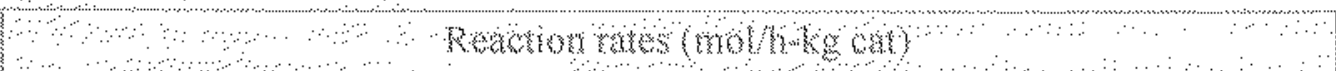 } \\
\hline & \multicolumn{4}{|c|}{$\therefore(\mathrm{v} O=2 \mathrm{~m} / 0)$} & \multicolumn{4}{|c|}{ 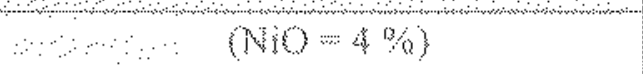 } \\
\hline & $20 \%$ & $240 \%$ & $3 / 3 \%$ & $3.8 \% \%$ & $205 \%$ & $2.40 \%$ & $3.13 \%$ & $3.89 \%$ \\
\hline 300 & 0,827 & 1378 & 2.747 & 4.023 & 3856 & 5.237 & $8.8 \%$ & 60932 \\
\hline me & 18 & 6 & $38 \%$ & 7332 & 376 & 76 & 62 & 894 \\
\hline 3 & 196 & 2,4 & ass & 10620 & 8.38 & 113 & 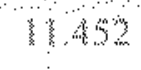 & $118 \%$ \\
\hline 300 & 32 & 4,35 & 643 & 479 & 11293 & 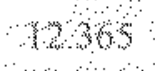 & mo & 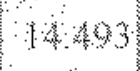 \\
\hline 380 & 45 & 6.183 & $\mathrm{Wl} / \mathrm{l}$ & 2062 & 13,32 & 663 & 17380 & 2068 \\
\hline 490 & 39 & 1045 & $: 462$ & 2444 & 1725 & $x+493$ & 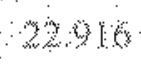 & $358 \%$ \\
\hline 4 & $\mathrm{H}, \mathrm{O}$ & $\mathrm{l}_{4}$ & 20,84 & $3 / 06$ & $2 \pi$ & 2,867 & $30 \%$ & $356 \%$ \\
\hline 40 & 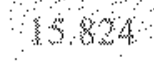 & 1839 & 27,37 & 39340 & 2832 & 3035 & 425 & 4484 \\
\hline 30 : & 2396 & 2632 & A4617 & 549 & $38, y$ & 40,5 & 468 & 45,37 \\
\hline 350 & 3,518 & anos & 6441 & 71628 & 4786 & $y^{2} y_{2}$ & $70 s$, & $80 \%$ \\
\hline
\end{tabular}


Tha more active sites on the survere than the lower ons. "The raxtion rate in afocter by the arrount of avankble active sites. Holner amount of active stres watures the increase of gatses to be reacted ard resulting on the higher reaction rate. Moreover, the results also show thet vamacium pentoxide catalyst is betret than nichel oxide. This can be explained using electron configuration. Vanadium has aton number 23 and the orbick can be wirten as $1 s^{2}-2 s^{2}-2 \mathrm{p}^{6}$. $3 s^{2}-3 w^{2}-4 s^{2}-3 d^{3}$. Nowel having atom munber

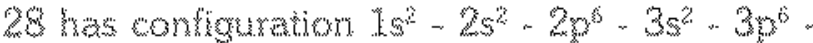

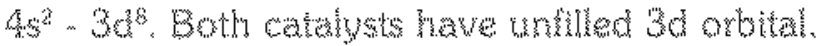
However, vanadium has more unparred glectron. than nickel. This couses the abkity of varachum as a catalyst in betrer than nickel.

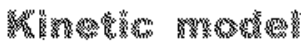

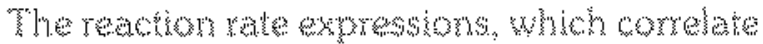

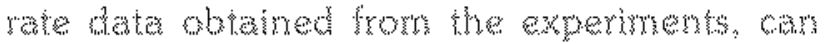
exther be empiricat of be developed on the basis

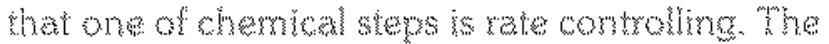

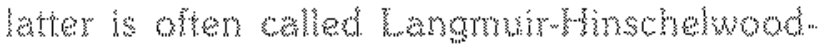

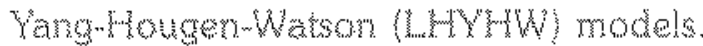

Power lan model

The power law moder for the reaction rate of

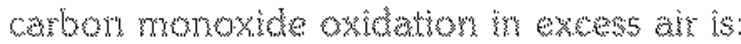

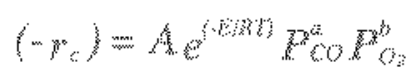

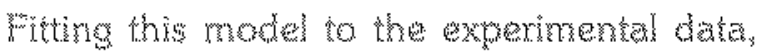
using simple linear regresum method, the parameters $A$, E, a and b were estabushed

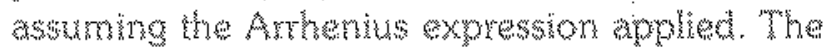
rasults can be seen in table 5 . From the power law model, the reactom rate lias besm found to be proportional to the nescative power of partiel pressure of $\mathrm{CO}$ or $\mathrm{CO}$ inhbition in the range of concentratons and semperature shdied. This prebicts an infinite reation rate as the wartal pressure of co approaches zero. Intwitively, on would expect that the reaction rate becomes 2 rer as the partial pressure approaches zero. This

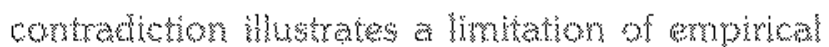
models. They canot be extrapoleted beyond the experimental range. "Therefore, a theoretical reaction rate model which ha a co partal pressure in the denomindor should be uset.

\section{Mecharistic model}

w both gasas $\left(\mathrm{CO}\right.$ and $\mathrm{O}_{3}$ ) are alsorbed on

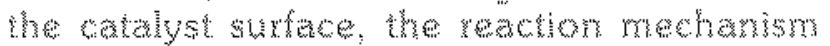

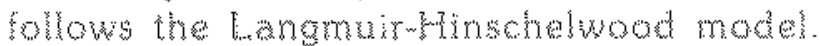
Howevor, if one of the redant is in the gas phess

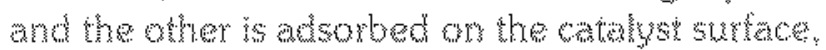

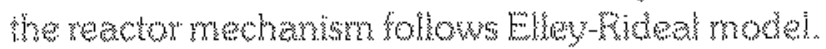

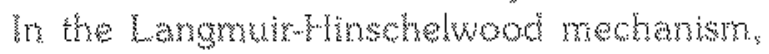
there are wo nodels:

Mocel 1: $C O$ and $O$, we adsorbed on the catalyst surtace then the rate expression is:

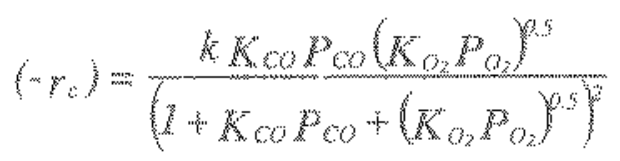

Model 2: Ir adsorpton of 0 in the form of 0 s. whe reaction rate expression is:

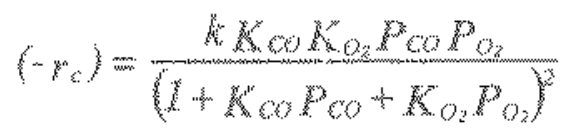

There are the models in the Eley Rideal mechumism

Model 3: Rection between Co in the gas phase and Actorber $\mathrm{O}_{2}$

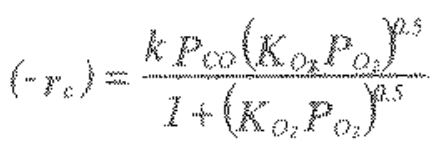


Modn a : Reacton bewreen 00 in the gas phase and adubod $\mathrm{O}_{2}$ in the fomm of $\mathrm{O}_{2} \mathrm{~s}$

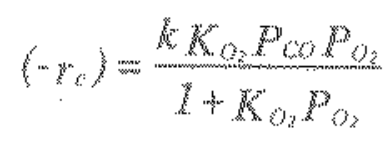

Model 5: Meaction merwern on in the gas phase arie adrobed $\mathrm{CO}$

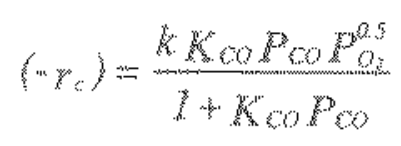

Fiturith the hinets model to the expermental data, tre parameter $k$, Ko and Kor were estoblished assuming the Ampentus expression for kas shown below.

$$
\begin{aligned}
& \text { K }=A \text { axp }\{E \mid R T\} \\
& K_{c o}=\text { a exp (b/RT) } \\
& h_{2}=c \exp (\text { d }
\end{aligned}
$$

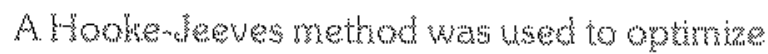
She all parameters.

From he madels above, model 2 is the best model for this reation simce it arves the minimum of Sunzs of Square of Errors (SSF), The rate expressions is as follows and the parameters are presented in "reble 6 :

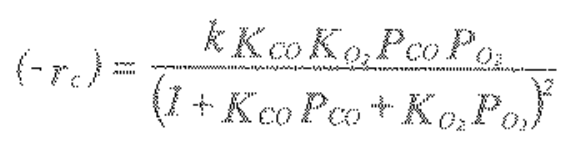

This rate expessian can predicthe reachon rate from zero to several perwert of $\mathrm{CO}$ ard doos not go to imfinity as the pratial pressure of 00 amproaches

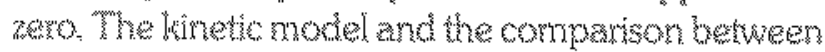

calculated and observed values show that knetic

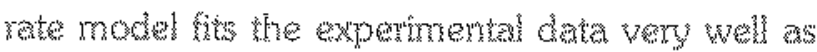
shown int Fures 3 and 4 . Statistical calculationg also show that the modet is an appropriate representation of he data since the coeticient of determinaton, Re, for all axperiments is close to one.

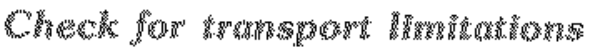

Mccording to Aris and Somoriay (1987) the importance of the twansport proceses in a watalytio reactor can be whiten as follows lin decreasing

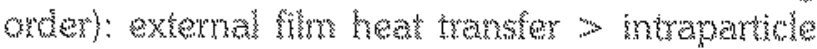
mass transport $\rightarrow$ external film mass transfar $>$ intraparticle heat transfer. To make sure that the reaction kinetics are not mashed by inker and intrapartick heat and mass twnsfer, the following mecasures were undertaken. By using smat particles, the etrect of intraparicle transport ata be elminated. In this study, catalyst perticles hsed were $40 / 50$ mesh size with average diemeter 3.58

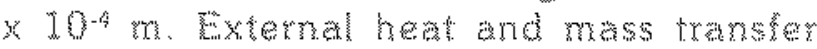
resistances on be rebled or elmimated by employing kigh volumatric flow rates. For a gren armount of catalyst, the upper lmit of llow rate; however, is limited by the detent abitimy of $\mathrm{CO}$ and CO by the IR. Futemal mas transfer interereno in a micro reator can be ictenthen by varying the

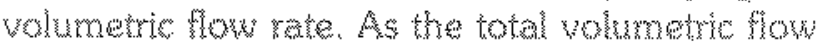

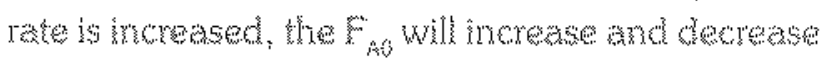
in the fractional conversion of xactert in the outhet

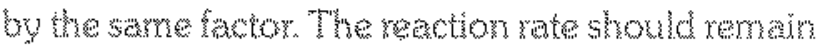
constant. However, if the readion rate dow change whin the fow rate, it means that the mass transfer

\begin{tabular}{|c|c|c|c|c|c|c|}
\hline \multirow[t]{3}{*}{ Catalyst } & \multicolumn{6}{|c|}{ Co oxidntion } \\
\hline & \multirow[t]{2}{*}{$\mathrm{A}$} & \multirow[t]{2}{*}{ Ei } & \multicolumn{4}{|c|}{ Rower for mechanistac model } \\
\hline & & & a & $b$ & 6 & d \\
\hline $\mathrm{V}_{2} \mathrm{O}(2 \%)$ & $3 \times 10^{5}$ & 14877 & 2.09 & 5459 & $2.16 \times 10^{5}$ & 12334 \\
\hline $\mathrm{V}_{2} \mathrm{O}_{5}(\mathrm{~A}$ & $3.7 \times 10^{2}$ & 13667 & 1.56 & 5433 & $2.31 \times 10^{5}$ & 12454 \\
\hline $\mathrm{NOO}(2 \%)$ & $42 \times 10^{5}$ & 11732 & 1.63 & 4845 & $2.14 \times 10^{3}$ & 11427 \\
\hline $\mathrm{NO}(a \%)$ & $46 \times 10^{5}$ & 1219 & 0.95 & 4926 & $2.55 \times 10^{-5}$ & 1332 \\
\hline
\end{tabular}
interterences is present. The resulsw show thet the reaction rate is not ateced by the volumetric flow rate suggesting that no important external mass transfer resistance is present. It also suggests that

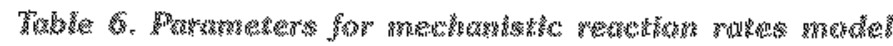



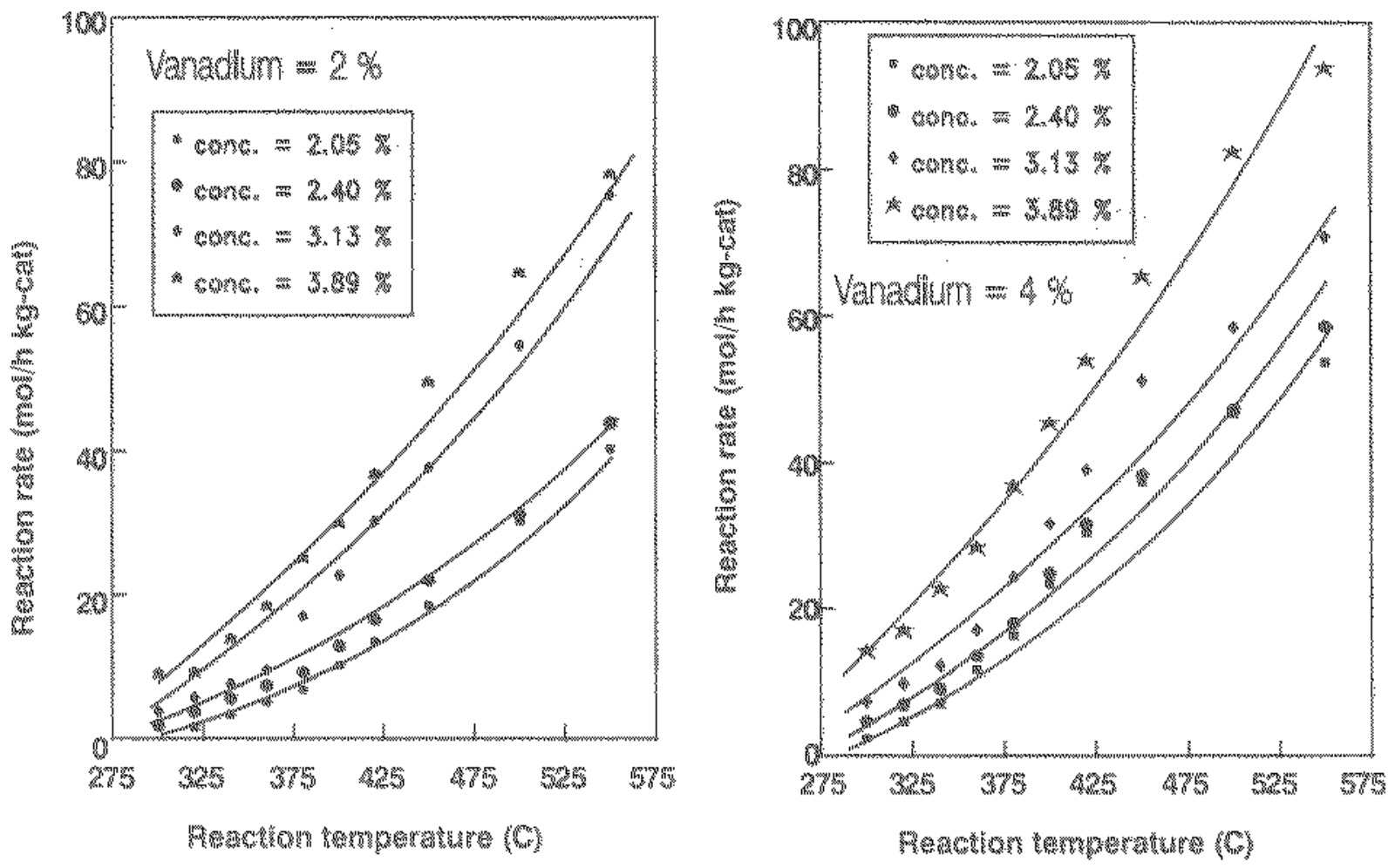

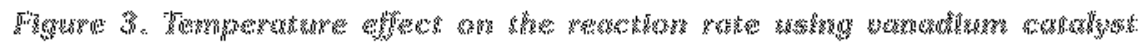
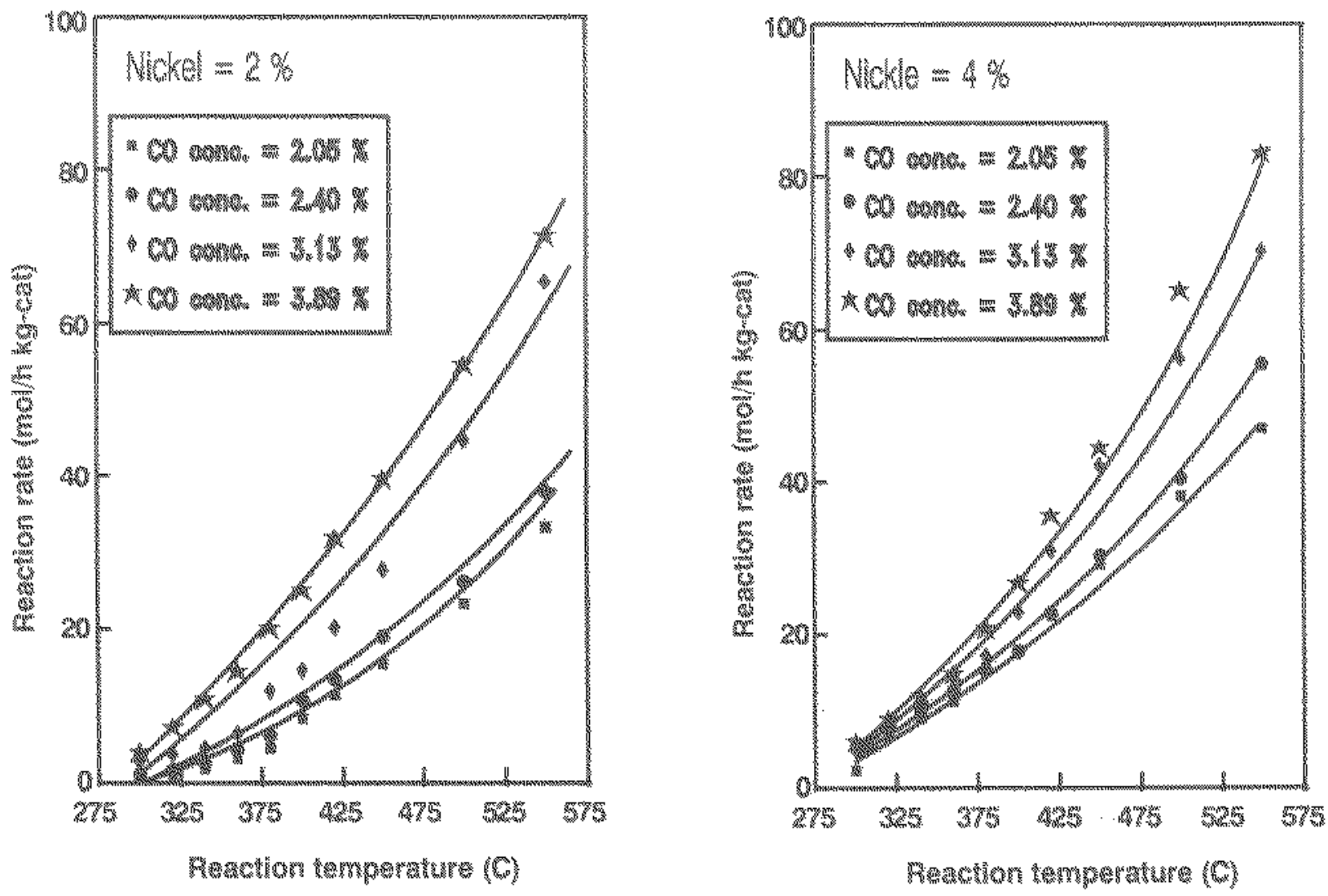

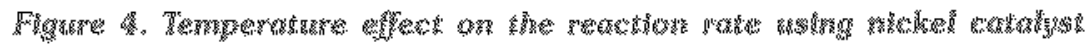


the combination of low conversion and high volumetric flow rate has made gas and particle temperatines equal.

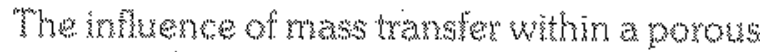
structure on observed ratur for $\mathrm{co}$ oxidaton has also beren cheked from eftectveness calculation (Froment and Biscrote, 1990 ) and tron I'tudgims cuterion $(972)$. "The resulys of these calculations show that the effectiveness factor for all experimerns is equar to 1 . This mens that there

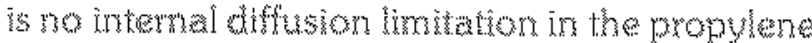
oxidathon, "The fudging criterion supported this conclusion. The values of "wudgins criterion are lass than 3.0

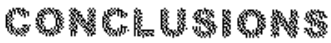

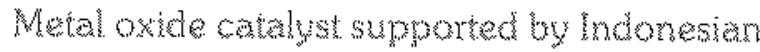
natural zeolte developed in the leboratory was comable for oxiding $\mathrm{CO}$. The oxidaton kinetich of 0 has been studien and the rate equation and aparent wetriation energy have bers determined. The results presented show the applicabitity of kinetro motalng based on elemertary processers. selected on the bass of mechanstic studiss, peraimu to the overall process of the $\mathrm{CO}$ oxidation by $\mathrm{O}$, aver metal oxide/natural reolste catalyst. This standard

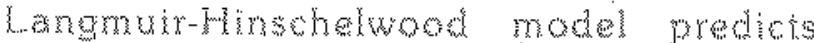

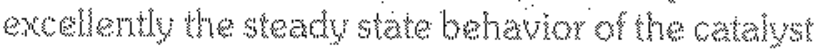
over a wide range of aperating conditum wor the conditions of the espenmerts and ype of colatalyst user in this work, it was established hat bulk phase mass transher and pore diknton resisumce do not contrel the rate of catalytic oxidation of $\mathrm{CO}$.

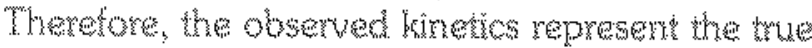
surface reactons rata. The minferential isothamal bed bata can be comelated egualy well by simple power law molel and mechanistic model.

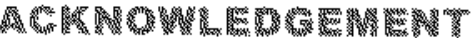

The author is gratsive for funding from Inclonesian Research Council (DRN) throus RUT project.

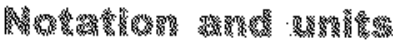

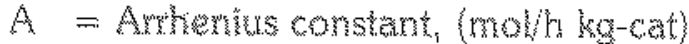

$$
\begin{aligned}
& E \text { - Activation enswo, cal/mol } \\
& \text { K w Reaction rate constant, (molh kg-cat) }
\end{aligned}
$$

$$
\begin{aligned}
& \mathrm{K} \text { =- Adsomption cosficient }
\end{aligned}
$$

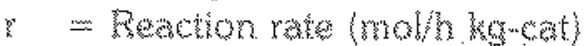

$$
\begin{aligned}
& \text { F = Gass constant, cal/ mol K } \\
& p=\text { Partial pressure } \\
& \text { T. = Temperature, } \mathrm{K}
\end{aligned}
$$

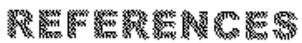

Aris, R. and Somorjai, G.A., 1987, "Catalyst Design", wohr Wiky and Sons. New Yonk.

Bates, d.R., 1988, "Occurence of Watural Zeotites prosent Status and Futura Research". Akdudrata Kado, Eudapest.

Barshad, $Y$ and Gutary, E, 1985, "A Dynamic Sumy of CO Oxidation on Supponted

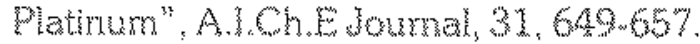

Foger, K., 1984, "Dispersed Metal Catalyst and Surface ...ab", Univessity of Meboume. Meboume.

Froment, 6. F. and Eischot: K, B., 1990 , "Chemical Remeror Analysis and Deshn",

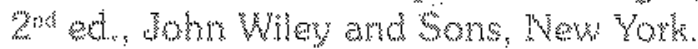
Hudgins, R.R., 972 "Criteria tor Transport Limitaton", Can. a. Clyem, 50, 427-428. Fusani and "rardjatro, 1996, "Natural Zeolite occurrences in thdonesiz", proc. Int. Sem on Novel Uses of Inorganic Natural

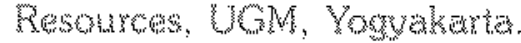

Whaten and Budiono, 1999. "An Afemative Activation Merwom hor Watural Zeoltefrom Indonesian Deposits Based on lts Chemical Properties", Prow int Workhop and sen. On Catalys Cherwisty, UGM, Yogy

Matros, YS, 1989 "Caralytic Processes under Unatadywtate Condtrons", Elsever, New Yonk.

Mc Charty. D.E, 1975, "Mechanim of CO Oxdaton", md Eng. Chem. Proc Des. Dev, 10, 541 545 .

Nishyame, Y and Wise, H, 197", "kineve Oxictation of Carbon Monoxide" "Chem. Eng. $50,32,50$.

Theodore, L and Bounicore, A. W, 1988, "Air Polution Control Eoumment" ChC Press Mo, Florida.

Volk, S, E., Morgan, C.R., Liederman, D. and Wacob, S.M., 1973, "Knetic Study of Carbon Monomide and propulene

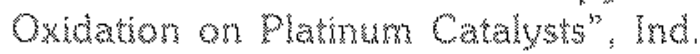

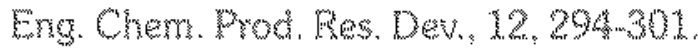

